\title{
Plant Sex Prediction Using Genetic Markers in Cultivated Yams (Dioscorea rotundata Poir.) in Benin
}

\author{
Narcisse Denadi 1,2,3, Christophe Gandonou 2(D), Antoine Abel Missihoun ${ }^{4}$, \\ Jeanne Zoundjihékpon ${ }^{3}$ and Muriel Quinet ${ }^{1, *(\mathbb{D})}$ \\ 1 Groupe de Recherche en Physiologie végétale-Earth and Life Institute, Université catholique de Louvain, \\ B-1348 Louvain-la-Neuve, Belgium; narcisse.denadi@uclouvain.be \\ 2 Laboratoire de Physiologie Végétale et d'Etude des Stress Environnementaux, Faculté des Sciences et \\ Techniques, Université d'Abomey-Calavi, Cotonou 01BP526, Benin; ganchrist@hotmail.com \\ 3 Laboratoire de Génétique Ecologique, Faculté des Sciences et Techniques, Université d'Abomey-Calavi, \\ Cotonou 01BP4521, Benin; agboyinou@gmail.com \\ 4 Laboratoire de Génétique Moléculaire et d'Analyse des Génomes, Faculté des Sciences et Techniques, \\ Université d'Abomey-Calavi, Cotonou 01BP526, Benin; missihoun_antoine@yahoo.fr \\ * Correspondence: muriel.quinet@uclouvain.be; Tel.: +32-10-47-34-43
}

Received: 31 July 2020; Accepted: 2 October 2020; Published: 6 October 2020

\begin{abstract}
Dioscorea rotundata Poir. is mainly dioecious but it also produces monoecious individuals. Recently two genetic markers were proposed to determine the sex in this species. We tested them in 119 individuals from 101 different cultivars of the national collection of Benin to verify whether they can predict the sex observed in the field. Among the analyzed individuals, 72 were male, 37 were female, 7 were monoecious and 3 were non-flowering. Our results showed that the marker sp16, associated with the W allele (female allele), was present in all female individuals but also in more than $42 \%$ of male individuals. Thus, while the absence of sp16 confirmed the male sex of the individuals, its presence did not allow sex discrimination. The marker sp1 allowed the identification of four genotypes (AA, $\mathrm{AB}, \mathrm{BB}$ and $\mathrm{AC}$ ) in the analyzed individuals with $\mathrm{AA}$ and $\mathrm{AB}$ being the most represented. Although AA was observed in $62.16 \%$ of female individuals and AB in $83.33 \%$ of male individuals, we did not observe a clear correlation between sp1 genotypes and sex identity. We concluded that the tested markers did not allow a clear sex discrimination in Beninese Dioscorea rotundata cultivars. Our results also suggest that Beninese D. rotundata cultivars have adopted a male $\mathrm{XX} / \mathrm{XY}$ heterogametic system that is undergoing reorganization.
\end{abstract}

Keywords: dioecy; monoecy; sex determination; sexual chromosome; yam

\section{Introduction}

The species Dioscorea rotundata Poir. is one of 600 species of the genus Dioscorea in the family Dioscoreaceae [1]. This genus is commonly known as yam and D. rotundata is described as white Guinea yam [2,3]. This species is also named Dioscorea cayenensis subsp. rotundata Poir. J. Miège or Dioscorea cayenensis-D. rotundata, depending on the authors [4-7]. Dioscorea rotundata is mainly dioecious, bearing male and female flowers on separate individuals, while some monoecious plants, bearing male and female flowers on the same individual, could be observed $[8,9]$. It is the most cultivated species in Benin [4], and Benin is the fourth largest producer of this species worldwide after Nigeria, Ghana and Côte d'Ivoire [10]. It is cultivated for tuber production and is an important source of food and income in Benin where yam is the staple food of the population [11]. However, despite its economic importance, this species remains largely disregarded by breeding programs [11]. The species still suffers from phytosanitary problems and is sensitive to environmental stress such as drought or 
flooding [12-15]. In sensitive cultivars, anthracnose, fungal or viral attacks may cause yield losses of about $15-25 \%$ [14-19].

Even though they are mainly multiplied by clonal propagation, more than $73 \%$ of Beninese D. rotundata cultivars flower [5] and produce fruits and seeds that allow sexual reproduction $[5,20,21]$. Although sexual reproduction offers opportunities for genetic improvement, breeders have to face several difficulties inherent to the species, such as a relatively long cultivation cycle ( 8 to 12 months), low germination and flowering rates, low flower fertility, heteroploidy [8] and especially spontaneous variations in sex from year to year [9]. These spontaneous variations in sex from year to year have not been clearly investigated yet, but they were observed in some cultivars by growers and researchers $[9,22]$. For example, clonal propagation of a bisexual plant could sometimes result in the next generation giving bisexual, unisexual or non-flowering plants. Similarly, clonal propagation of a unisexual plant may sometimes give unisexual, bisexual or non-flowering plants in the next generation. Spontaneous variations in sex have caught the attention of many researchers since it undermines experimental designs, particularly those involving cross-pollination. This sex variation has also raised the question on the control of sex determination in D. rotundata $[9,22]$.

Over the last decades, much research has focused on identifying phenotypic traits (stem and leaf color, presence or absence of wax, stains on stems, leaf shape, etc.) that would make it possible to predict the sex of plants before flowering [23]. Furthermore, correlations between sex and ploidy level were also sought, as the species is characterized by a strong heteroploidy [9,23]. In Benin, cultivars previously described as tetraploid, hexaploid and octoploid for a base chromosome number $X=10[4,6]$ are actually described as, respectively, diploids, triploids and tetraploids with a base chromosome number $X=20$ [22-26]. With the development of high-throughput sequencing, the genome of D. rotundata has been sequenced, making it possible to identify a sex-linked candidate chromosomal region and to develop genetic markers for sexual identification [22]. Based on a cleaved amplified polymorphic sequence (CAPS, sp1) marker, Tamiru et al. [22] demonstrated that in D. rotundata sex determination was under the control of a ZZ/ZW (female heterogametic) system as opposed to the XX/XY (male heterogametic) system described in other Dioscorea species such as D. alata [27], D. floribunda [28] or D. tokoro [27]. Tamiru et al. [22] also identified a female specific chromosomic region, which led them to develop the marker sp16 to discriminate male plants from female, monoecious and non-flowering plants [22]. This marker allowed identifying the sex of several D. rotundata breeding accessions from the collection of the International Institute of Tropical Agriculture (IITA) in Nigeria [22]. A SuperSAGE transcriptomic study was also undertaken to identify genes linked to flowering and sex in this species and identified candidate genes whose expression differed according to sex [9].

In this context, our study aimed to investigate whether the markers sp16 and sp 1 allow sex discrimination in cultivated D. rotundata yams from Benin. These markers were tested in 119 yam individuals from 101 different cultivars grown in Benin and compared to the sex observed in the field. The relationship between the level of ploidy, sex and genetic markers was also investigated. We further discussed whether cultivars of the species D. rotundata in Benin are regulated by a ZZ/ZW (heterogametic female) or XX/XY (heterogametic male) system based on the sp1 marker.

\section{Materials and Methods}

\subsection{Plant Material}

We analyzed 119 yam individuals from 101 different cultivars of D. rotundata from the national collection of the Centre de Recherche, de Formation, d'Incubation et d'Innovation pour le Développement Agricole (CREFIISDA, Zogbodomey, Benin, $\left.6^{\circ} 56^{\prime}-7^{\circ} 08 \mathrm{~N}, 1^{\circ} 58^{\prime}-2^{\circ} 24^{\prime} \mathrm{E}\right)$. Of the 119 analyzed individuals, 72 were male, 37 were female, 7 were monoecious and 3 were non-flowering based on field observations. As some cultivars have differential sex, individuals of certain cultivars showing different sex based on historical data/personal observations over years and locations were analyzed separately, while only one individual per cultivar was analyzed for cultivars with stable sex 
(Table S1). The different cultivars were named according to Dansi et al. [29] to avoid any redundancy due to synonymy. Plants were grown in Benin under field condition at CREFIISDA (Zogbodomey, Benin, $6^{\circ} 56^{\prime}-7^{\circ} 08 \mathrm{~N}, 1^{\circ} 58^{\prime}-2^{\circ} 24^{\prime}$ E). Sowing was performed on 8 May 2019. For each individual, young healthy leaves were collected for DNA extraction. Leaf harvesting was performed after flowering to clearly identify the sex of each individual.

Cultivars were classified as having stable or unstable sex based on the literature $[2,4,20,29,30]$, previous personal observations made during survey campaigns (2017-2018) and observations made during this study (2019). A cultivar was considered as having unstable sex if the described or observed sex varied across years and/or locations. A cultivar was considered to have stable sex if the sex described or observed was always the same whatever the year and location. The flowering history of the studied cultivars is summarized in Table S1. The ploidy level of the cultivars is also mentioned in Table S1 when available (adapted from Dansi et al. [4], with $X=20$ [22] instead of $X=10$ [4]). Dansi et al. [4] determined ploidy level by chromosome counting and flow cytometry.

\subsection{DNA Extraction, Amplification of the Genetic Markers and Sequencing}

Genomic DNA was extracted from frozen grounded leaves according to Fulton et al. [31]. The concentration and quality of DNA were checked using the NanoDrop ND-1000 (Isogen Life Science, De Meern, The Netherlands). For specific amplification of sp1, sp16 and Dr-Actine [22], we used GoTaq DNA polymerase (Promega, Leiden, The Netherlands), $25 \mathrm{ng}$ of plant DNA as a template and specific primers (Table 1) according to the manufacturer's instructions. After an initial denaturation step at $95{ }^{\circ} \mathrm{C}$ for $2 \mathrm{~min}$, each cycle consisted of $20 \mathrm{~s}$ at $95^{\circ} \mathrm{C}, 30 \mathrm{~s}$ at an annealing temperature depending on the primer combination and $1 \mathrm{~min}$ extension at $72{ }^{\circ} \mathrm{C}$, followed by a final extension of $5 \mathrm{~min}$ at $72{ }^{\circ} \mathrm{C}$. The primer pairs, annealing temperature and number of cycles used for each amplification are presented in Table 1. Dr-Actine was used as a positive control (housekeeping gene, used for normalizing the PCR amplifications). PCR amplifications were performed in triplicates. For the sp1 marker, the PCR products were cut with EcoRI (New England Biolabs Inc., Frankfurt, Germany). The PCR products were then resolved on agarose gels.

Table 1. List of primers used in this work.

\begin{tabular}{|c|c|c|c|c|}
\hline Marker & Primer Sequences & $\mathrm{Tm}$ & Cycles & Size (bp) \\
\hline Dr-Actine & $\begin{array}{c}\text { F: } 5^{\prime} \text {-CAGGGAAAAGATGACCCAAATC-3 } \\
\text { R: 5'-CCATCACCAGAATCCAGCAC-3 }\end{array}$ & $55^{\circ} \mathrm{C}$ & 35 & $\sim 250 \mathrm{bp}$ \\
\hline $\mathrm{sp} 1$ & $\begin{array}{c}\text { F: 5'-GATCTGGCTTCCTCCATCTTG-3' } \\
\text { R: 5'-GCTTGGGTGGTTAGTTTATTGTTTG-3' }\end{array}$ & $52{ }^{\circ} \mathrm{C}$ & 40 & 854 bp \\
\hline sp16 & $\begin{array}{l}\text { F: 5'-AATGTGTTTAACAGGGTGAATTC-3' } \\
\text { R: 5'-GAATTCAGCCGAATATACTTATTC-3' }\end{array}$ & $52{ }^{\circ} \mathrm{C}$ & 40 & $262 b p$ \\
\hline
\end{tabular}

Amplified fragments for sp16 were sequenced in five cultivars (two females and three males) in order to compare the nucleotide sequences (three independent sequencings per cultivar). The PCR products were either directly sequenced or sequenced after cloning using the TOPO ${ }^{\text {TM }}$ TA Cloning ${ }^{\mathrm{TM}}$ Kit for sequencing (Thermo Fischer Scientific, Waltham, MA, USA) and TOP10 chemically competent cells according to the manufacturer's instructions. Transformed colonies were identified by PCR and transformed plasmids were extracted using GeneJET Plasmid Miniprep Kit (Thermo Fischer Scientific, Waltham, MA, USA). PCR products and plasmids were sequenced with Genetic Analyser 3100 (Applied Biosystems, Foster City, CA, USA) using Big Dye Terminator V1.1 cycle sequencing kit (Applied Biosystems, Foster City, CA, USA) and sp16F and R or T3 and T7 primers. Sequences were aligned using BioEdit 7.2 software. 


\subsection{Data Analysis}

All statistical analyzes were performed with R Software Version 3.6.1 [32]. Descriptive analyzes were performed to associate the sex of the cultivars with the genotypes observed for the markers sp16 and sp1. A bivariate distribution of the genotypes of sp16 and sp1 (before digestion) conditional to the sex allowed us to measure the impact of secondary amplifications generated by sp 1 on the sex change in some individuals carrying sp16. Finally, a multiple component analysis (MCA) was performed using the MCA function of the FactoMineR package to evaluate possible associations between the sex of the cultivars and the genotypes obtained for the different markers.

\section{Results}

\subsection{Floral Characteristics of Beninese Yam Cultivars}

The 119 investigated individuals were grouped into six categories based on their sexual phenotypes in the field (Table S1). Differences between male, female and monoecious inflorescences are presented in Figure 1. Forty-eight individuals were male and belonged to cultivars that produced only male inflorescences whatever the location and season based on the literature and personal observations (Table S1). We described them as stable or typical males (M). Twenty-four individuals were male and belonged to cultivars with unstable sex, since sex variation was reported for these cultivars based on the literature and personal observations (Table S1). We described them as unstable or atypical $(\mathrm{M}+)$ males. Eighteen individuals were female and belonged to cultivars with a stable female sex based on the literature and personal observations (Table S1). We described them as stable or typical females (F). Nineteen individuals were female and belonged to cultivars that changed sex depending on location or season based on the literature and personal observations (Table S1). They were called unstable or atypical females $(\mathrm{F}+)$. Seven individuals were monoecious and belonged to cultivars that flowered generally or were occasionally monoecious $(\mathrm{O})$ (Table S1). The last three individuals were non-flowering (NF).
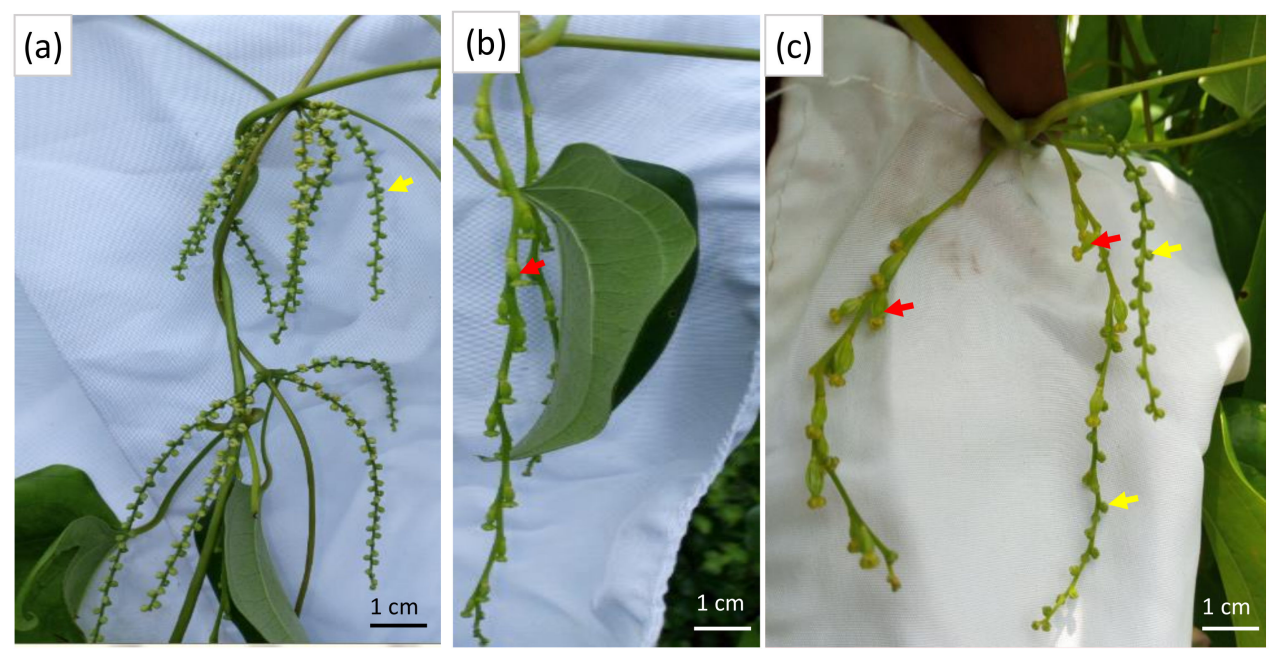

Figure 1. Inflorescences of (a) male, (b) female and (c) monoecious individuals of D. rotundata grown under field condition at the Centre de Recherche, de Formation, d'Incubation et d'Innovation pour le Développement Agricole (CREFIISDA) (Zogbodomey, Benin) four months after sowing (three months after tuber germination). Yellow arrows and red arrows indicate, respectively, male and female flowers.

\subsection{Use of the Marker sp16 to Discriminate Sex in Beninese Yam Cultivars}

According to Tamiru et al. [22], the sp16 marker corresponds to the $\mathrm{W}$ allele which is present in female individuals. Our results showed that within cultivars of the species D. rotundata from Benin, the marker sp16 amplified mainly in female and monoecious individuals compared to male and 
non-flowering individuals (Figure 2a, Table S1). Indeed, 36 of the 37 female individuals (F and F+) amplified the sp16 marker including all the F individuals (Figure 2b). The F+ individual without sp16 amplification belonged to the cultivar Ossousouhoun (syn. Ossoukpana). All monoecious (O) individuals also amplified the sp16 marker (Figure $2 \mathrm{~b}$ ). Thus, the $\mathrm{W}$ allele was present in all female (F) and monoecious $(\mathrm{O})$ cultivars studied. For male (M and $\mathrm{M}+$ ) individuals, 34 out of 72 showed amplification for the sp16 marker (Figure 2b, Table S1), suggesting that $47.22 \%$ of male individuals carried the $\mathrm{W}$ allele. When considering only male cultivars with stable sex (M), sp16 amplification was observed in $35.42 \%$ of the individuals (Figure 2b, Table S1). However, $70.83 \%$ of $\mathrm{M}+$ individuals showed amplification for sp16 and carried the $\mathrm{W}$ allele.

(a)

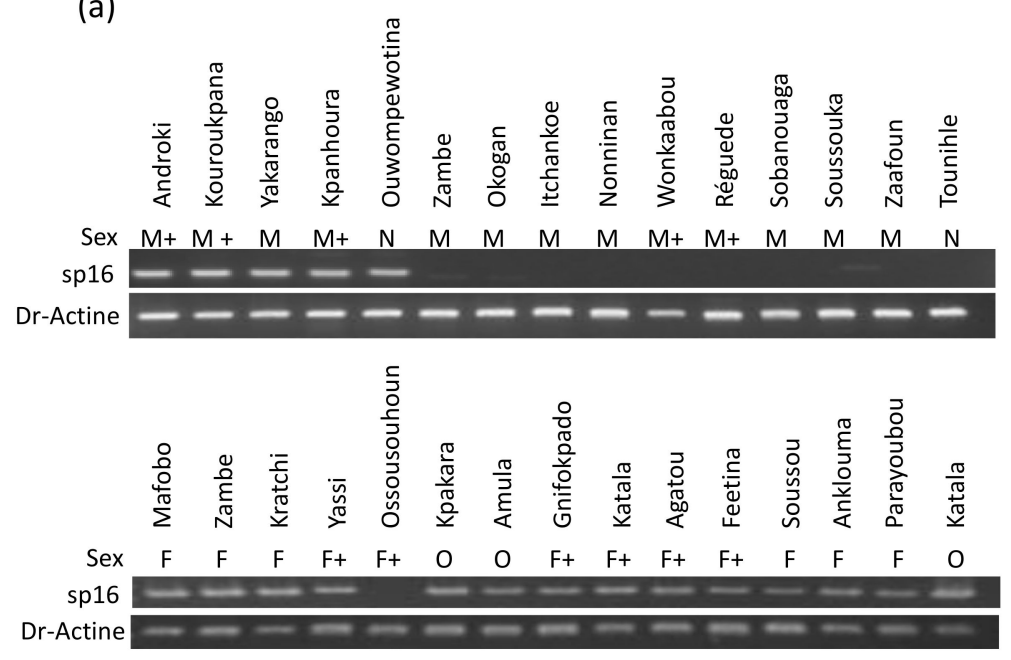

(b)

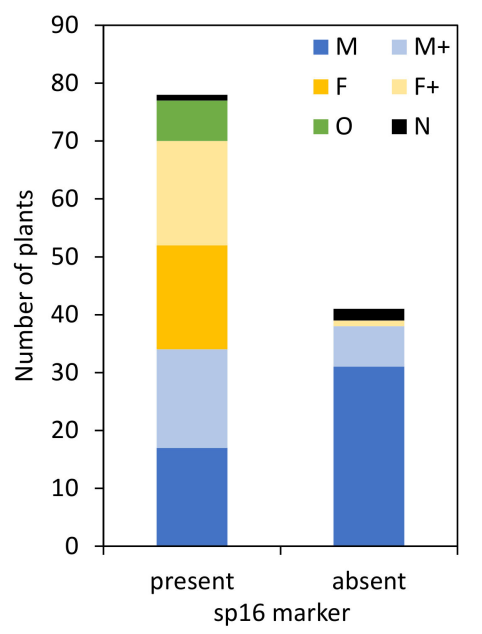

Figure 2. Analysis of the genetic marker sp16 in cultivars of D. rotundata from Benin. (a) PCR amplification for sp16 and Dr-Actine in a few cultivars. Dr-Actine is used as a positive control. (b) Distribution of individuals according to their sex identity and the presence or absence of the sp 16 marker. $\mathrm{M}$, stable male; $\mathrm{M}+$, unstable male; $\mathrm{F}$, stable female; $\mathrm{F}+$, unstable female; $\mathrm{O}$, monoecious; and N, non-flowering. The gels with markers are available in the (Supplemental data Figure S2).

The amplified sequences for sp16 were compared between two female and three male individuals from different cultivars, and the nucleotide sequences were identical whatever the sex and the cultivar (Figure S1), suggesting that this fragment of the $\mathrm{W}$ allele is the same in female and male individuals, when present.

\subsection{Use of the Marker sp1 to Discriminate Sex in Beninese Yam Cultivars}

The CAPS marker sp1 was developed by Tamiru et al. [22] and allowed discrimination between homozygous male (ZZ) and heterozygous female (ZW) individuals in D. rotundata. Digestion of the sp1 fragment by the EcoRI enzyme showed four different genotypes in cultivated $D$. rotundata yams from Benin, namely $\mathrm{AA}, \mathrm{AB}, \mathrm{BB}$ and $\mathrm{AC}$ (Figure $3 \mathrm{a}, \mathrm{b}$ ). $\mathrm{AA}$ and $\mathrm{BB}$ genotypes were the most frequent and were observed in $60.5 \%$ and $31.1 \%$ of individuals, respectively, while $\mathrm{BB}$ and $\mathrm{AC}$ genotypes were observed in only $5.9 \%$ and $2.5 \%$ of the individuals, respectively. As shown in Figure 3c, $62.16 \%$ of female $(\mathrm{F}$ and $\mathrm{F}+)$ individuals were of $\mathrm{AA}$ genotype and $83.33 \%$ of male $(\mathrm{M}$ and $\mathrm{M}+)$ individuals were of $\mathrm{AB}$ genotype. The six individuals of genotype $\mathrm{BB}$ were male. The $\mathrm{AC}$ genotype was rare and distributed among different sexual types (present in one female, two males and two monoecious individuals). We observed that the male sex was more often associated with the genotype $\mathrm{AB}$ (or $\mathrm{BB}$ but low frequency), while female sex was more often associated with the genotype AA. Nevertheless, the marker sp1 did not allow systematic discrimination between male and female sex in cultivated D. rotundata yams from Benin. 
(a)
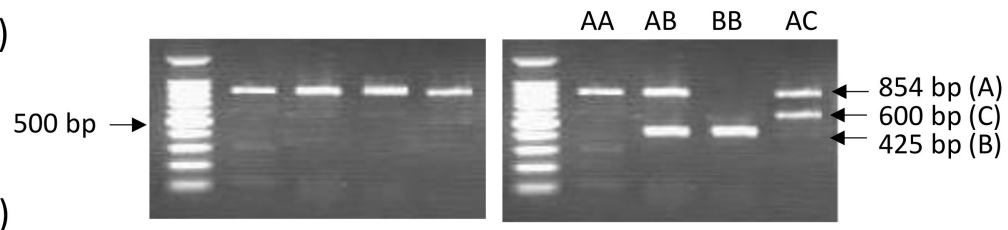

(b)

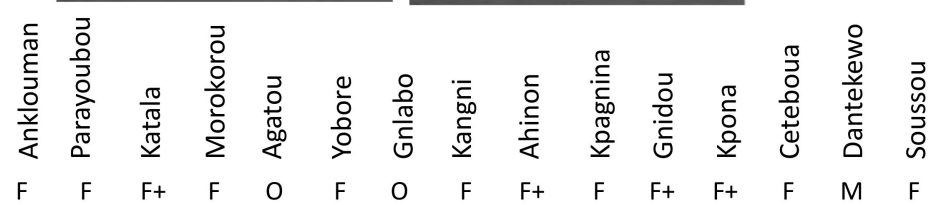
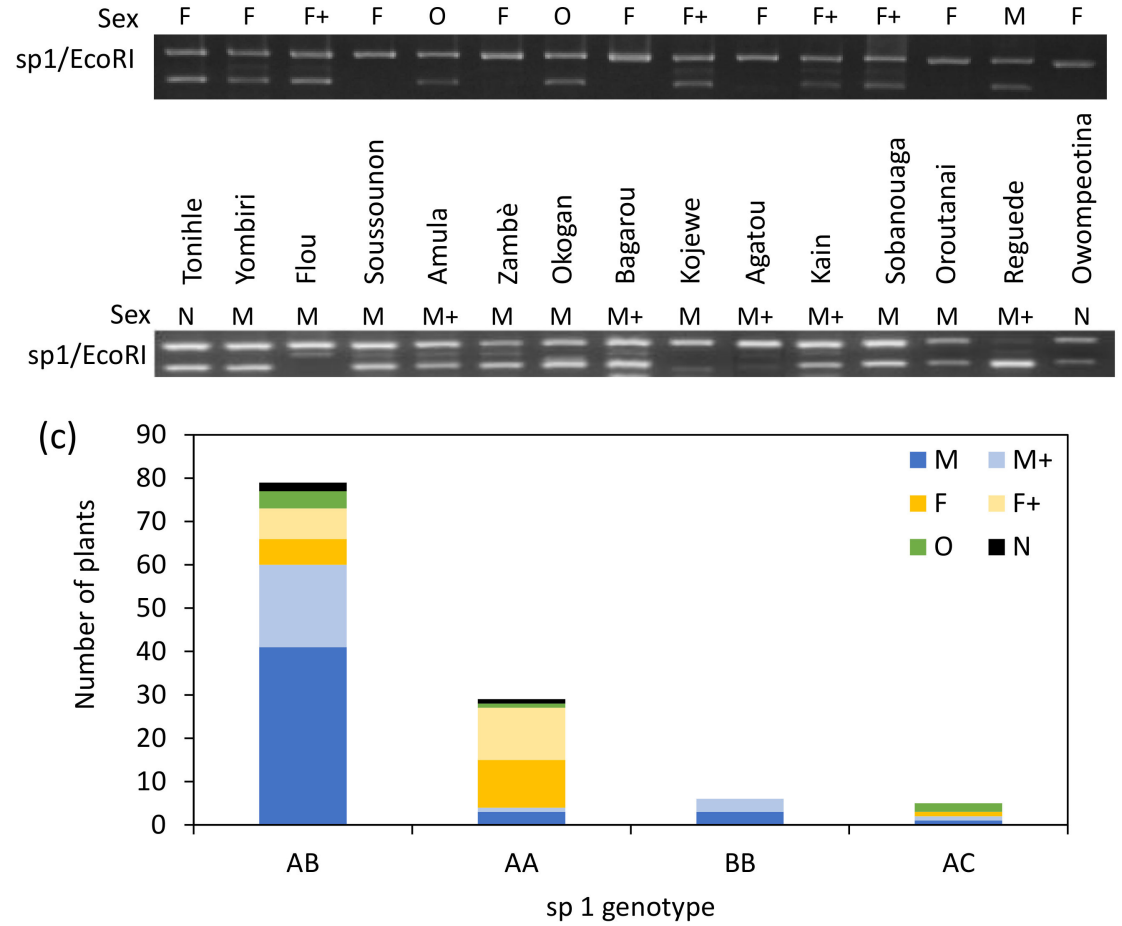

Figure 3. Analysis of the genetic marker sp1 in cultivars of the D. rotundata species of Benin. (a) The four profiles obtained before (left) and after (right) restriction with EcoRI. (b) PCR amplification and restriction for $\mathrm{sp} 1$ in a few cultivars. (c) Distribution of individuals according to their sex identity and the genotypes ( $\mathrm{AB}, \mathrm{AA}, \mathrm{BB}, \mathrm{AC})$ for the sp1 marker. $\mathrm{M}$, stable male; $\mathrm{M}+$, unstable male; F, stable female; $\mathrm{F}+$, unstable female; $\mathrm{O}$, monoecious; and $\mathrm{N}$, non-flowering.

Amplification of the sp1 marker led to secondary amplifications in some cultivars of $D$. rotundata in addition to the $854 \mathrm{bp}$ band that was present in all individuals (Figure 4a). Secondary amplifications of low intensity and variable size (sp1OA) were indeed observed in 60\% of studied individuals (Figure 4). The frequency of these secondary amplifications was particularly high in unstable male $(\mathrm{M}+)$ and female $(\mathrm{F}+)$ individuals which showed a band for the sp16 marker (Figure 4, Table S1). As shown in Table 2, 57.17\% of the unstable male (M+) individuals carried the $\mathrm{W}$ allele (sp16 marker) and showed sp1OA. Similarly, $63.16 \%$ of the unstable female $(\mathrm{F}+)$ individuals carried the $\mathrm{W}$ allele (sp16 marker) and showed sp1OA. Thus, the combined presence of the $\mathrm{W}$ allele and sp1OA could be a sign of sexual instability. 


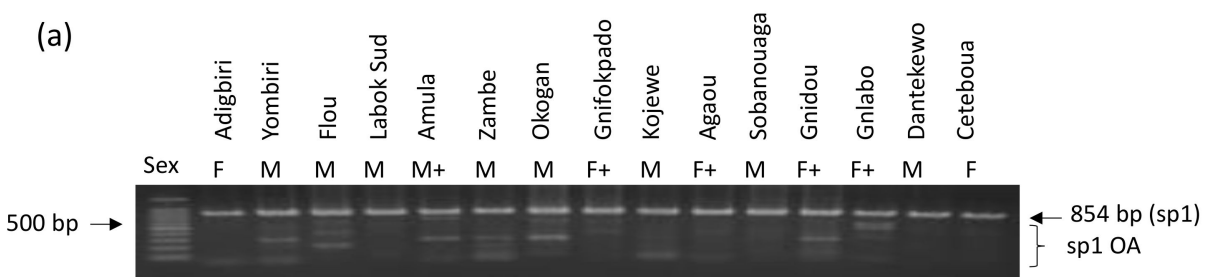

(b)

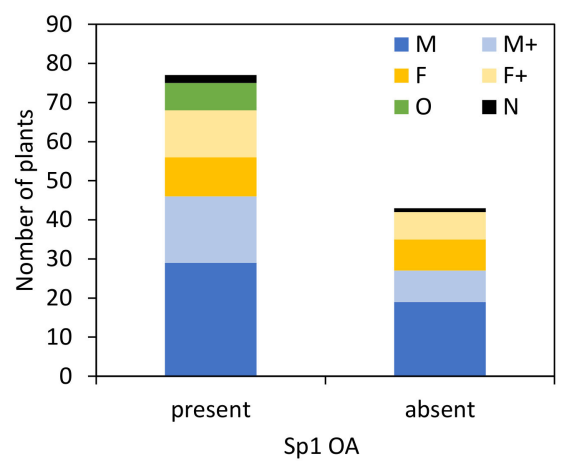

Figure 4. Presence of multiple amplifications for the sp1 marker before restriction in some cultivars of D. rotundata from Benin. (a) PCR amplification of sp1 before restriction in a few cultivars. (b) Distribution of individuals according to their sex identity and the presence or absence of multiple bands for the sp1 marker (sp1 OA) before restriction. $\mathrm{M}$, stable male; $\mathrm{M}+$, unstable male; $\mathrm{F}$, stable female; $\mathrm{F}+$, unstable female; $\mathrm{O}$, monoecious; and $\mathrm{N}$, non-flowering.

Table 2. Impact of the presence of the sp16 marker and the secondary amplifications for the sp1 marker (sp1 OA) on the frequency of unstable male $(\mathrm{M}+)$ and female $(\mathrm{F}+)$ individuals of $D$. rotundata from Benin.

\begin{tabular}{ccccc}
\hline & \multicolumn{2}{c}{ Male (M+) } & \multicolumn{2}{c}{ Female (F+) } \\
\cline { 2 - 5 } & sp1OA absent & sp1OA present & sp1OA absent & sp1OA present \\
\hline sp16 absent & $12.50 \%$ & $16.67 \%$ & $5.26 \%$ & $0.00 \%$ \\
sp16 present & $16.67 \%$ & $57.17 \%$ & $31.58 \%$ & $63.16 \%$ \\
\hline
\end{tabular}

\subsection{Relative Importance of sp16 and sp1 Markers in Sex Identification in Beninese Cultivars}

In order to understand the extent to which each of the two markers explain the sex of $D$. rotundata cultivars from Benin, a multiple component analysis was carried out (Figure 5). The first two dimensions explained $25.7 \%$ and $16.4 \%$ of the variability, respectively. The first dimension separated male and female individuals according to the sp16 marker. The absence of the sp16 marker was more associated with male individuals and especially with stable male individuals $(\mathrm{M})$ compared to unstable ones $(\mathrm{M}+)$. The second dimension distinguished stable male $(\mathrm{M})$ and female $(\mathrm{F})$ individuals from unstable $(\mathrm{M}+$ and $\mathrm{F}+$ ) individuals based on the presence or absence of sp1 OA. Unstable individuals ( $\mathrm{F}+$ and $\mathrm{M}+$ ) were most often associated with the presence of sp1OA so that, combined with the presence of sp16, secondary amplification at sp1 increased the frequency of male and female cultivars of unstable sex. With respect to the sp1 marker, the AA genotype was more often associated with female individuals while the $\mathrm{AB}$ and $\mathrm{BB}$ genotypes were more often associated with male individuals. From this analysis, it appears that the best determinant of stable male cultivars is the absence of the sp16 marker and that the best determinant of stable female cultivars is the AA genotype of the sp1 marker. 


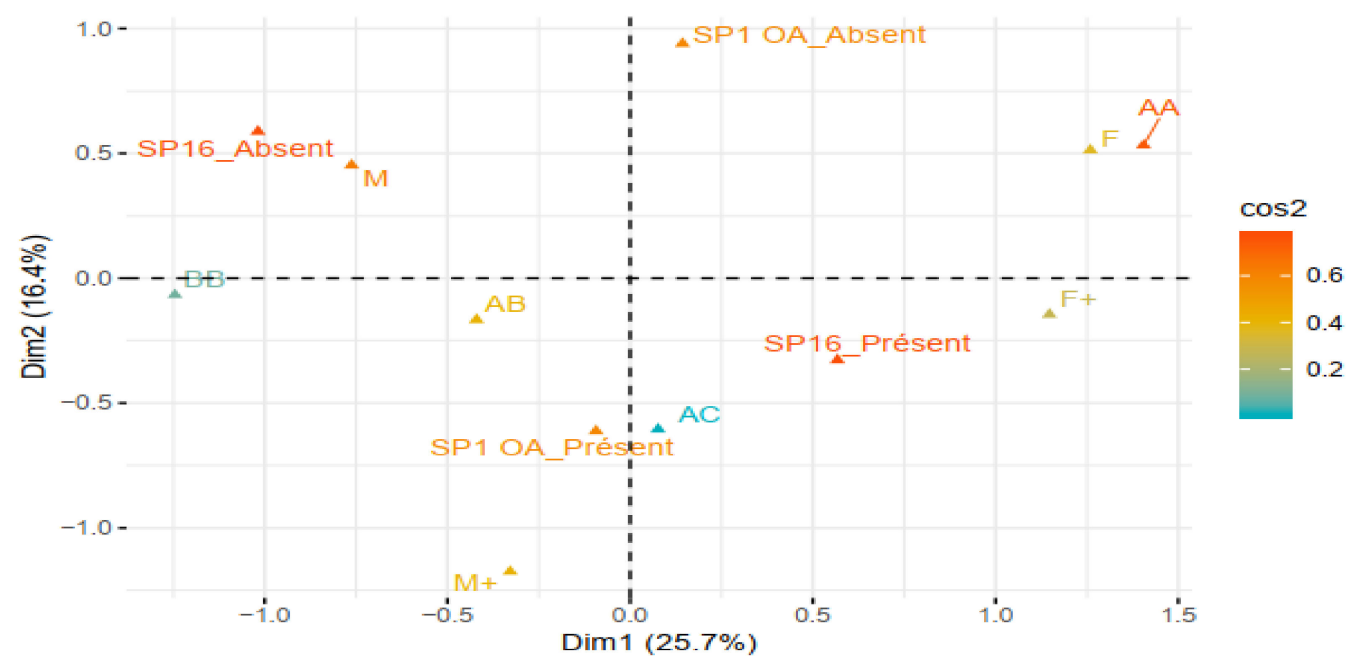

Figure 5. Multiple component analysis (MCA) of the relationship between the sex of D. rotundata cultivars from Benin and the markers sp16 and sp1. M, stable male; $\mathrm{M}+$, unstable male; F, stable female; $\mathrm{F}+$, unstable female; $\mathrm{O}$, monoecious; $\mathrm{N}$, non-flowering; and sp1 $\mathrm{OA}$, presence of multiple amplifications for the sp1 marker. The color codes from red to blue (for a cos 2 from the highest to the lowest) indicate the decreasing representativeness of the variables.

\subsection{Ploidy Level and Sex Expression}

The majority of cultivated $D$. rotundata yam individuals analyzed in this study were diploid with a base number $X=20[4,22,23,25,26]$ (Table S1). Among the 119 individuals analyzed, 2 were triploid and 2 were tetraploid (revised from Dansi [4], Table S1). All individuals tested with a ploidy level greater than $2 X$ were male or non-flowering and showed amplification for the marker sp16 and the genotype $\mathrm{AB}$ for the sp1 marker (Table 3). Although the number of triploid and tetraploid individuals was too small to assess the interference of ploidy level on the $\mathrm{W}$ allele, our results suggest that cultivars with ploidy greater than $2 \mathrm{X}$ are male or non-flowering despite the presence of the $\mathrm{W}$ allele.

Table 3. Impact of polyploidy on sex identity and genotypes for the sp16 and sp1 markers.

\begin{tabular}{ccccc}
\hline Cultivar & Ploidy Level & Sex $^{\mathbf{1}}$ & $\begin{array}{c}\text { sp16 } \\
\text { Marker }\end{array}$ & sp1 Marker \\
\hline Baridjo & $3 \mathrm{X}$ & $\mathrm{M}$ & Present & $\mathrm{AB}$ \\
Doundoua & $4 \mathrm{X}$ & $\mathrm{M}$ & Present & $\mathrm{AB}$ \\
Owompeotina & $3 \mathrm{X}$ & $\mathrm{N}$ & Present & $\mathrm{AB}$ \\
Alakissa & $4 \mathrm{X}$ & $\mathrm{M}$ & Present & $\mathrm{AB}$ \\
\hline
\end{tabular}

${ }^{1} \mathrm{M}$, male; $\mathrm{N}$, non-flowering.

\section{Discussion}

\subsection{Discriminating Power of the sp16 Marker and Link between the W Allele and Sex Determination}

Analysis of our results showed that absence of the sp16 marker could be associated with male identity, but its presence did not systematically imply a specific sex. These results are in agreement with those of Tamiru et al. [22]. Indeed, for Tamiru et al. [22], there is a specific region linked to the female sex characterized by the $\mathrm{W}$ allele that is able to partially (partial dominance) or totally (complete dominance) suppress the effect of the male $\mathrm{Z}$ allele. These authors hypothesized that this Z-suppressing function can be affected by the environment [22]. As a result, the ZW genotype determines generally female or monoecious identity but may also identify, in some cases, non-flowering phenotypes, while the ZZ genotype always leads to male identity. However, when the Z-suppressor effect of the $\mathrm{W}$ allele fails completely, a male individual could be obtained with a ZW genotype [22]. 
According to these authors, male sex is the default sex and the $\mathrm{W}$ allele could be influenced by the environment [22]. The importance of environment on the sexual control of yams has indeed been repeatedly stated [33-36]. However, according to our results, the $\mathrm{W}$ allele was present in female individuals but also in more than $42 \%$ of the male individuals of $D$. rotundata from Benin. In addition, the sequence of the marker was identical between male and female individuals and therefore did not allow sex discrimination. Thus, the sp16 marker did not allow clear sex discrimination in cultivated white Guinea yam from Benin, while it allowed sex discrimination of improved IITA Dioscorea rotundata varieties from Nigeria [22]. If the environment is responsible for modulations of the Z-suppressive effect of the $\mathrm{W}$ allele as proposed by Tamiru et al. [22], it would play a significant role in sex determination in D. rotundata cultivated yams from Benin. Indeed, some Beninese cultivars change spontaneously from sex identity depending on the year and region as we have observed (Table S1). However, no formal proof of the impact of the environment on the $W$ allele has been obtained yet. Further studies will thus be required to analyze sex-switch from year to year and the impact of the environment on sex determination in D. rotundata. Moreover, individuals with different sex were observed for a same cultivar in the frame of this study, although they were cultivated in the same conditions (Table S1). This suggests that sex instability could not only be explained by environmental conditions.

However, given that more than $35 \%$ of stable male individuals carried the $\mathrm{W}$ allele, we may not exclude that more than one locus are involved in sex determination in white Guinea yam. In their SuperSAGE transcriptome profile, Girma et al. [9] identified 88 tags that were differently expressed between male, female and monoecious individuals. Eighteen of them corresponded to genes known for their involvement in sex determination or floral development in other species [9]. In particular, DnaJ-like protein and Transketolase were specific for sex determination [9]. The latter is located on the chromosomal region linked to the sp1 marker and $\mathrm{Z}$ and $\mathrm{W}$ alleles $[9,22]$. On this basis, we cannot exclude that the presumed $\mathrm{W}$ allele corresponds to one gene among many others that interact to determine sex expression.

Furthermore, genomic analyzes of Tamiru et al. [22] were carried out on diploid cultivars whereas polyploid cultivars were also observed in $D$. rotundata $[9,23]$. The ploidy level can also affect sex determination. We observed that individuals with a ploidy level higher than $2 X$ flowered male or were non-flowering despite the presence of the W allele (sp16). Girma et al. [9,23] also observed that cultivars with a high ploidy level were always male or non-flowering. Further investigations are required to understand the interaction between ploidy level and genetic control of sex identity.

\subsection{Homo/heterogametic System in D. rotundata}

The sp1 marker is a CAPS marker associated with a region close to the $Z$ allele, which allowed Tamiru et al. [22] to demonstrate that sex identity of $D$. rotundata is governed by a ZZ/ZW (heterogametic female) system. The use of this marker in our study revealed four genotypes (AA, AB, BB and AC) in cultivated white Guinea yam from Benin with a very low frequency of $B B$ and $A C$ genotypes. These results contrasted with the observations of Tamiru et al. [22]. Such a discrepancy could be explained by the difference of analyzed material. Indeed, Tamiru et al. [22] investigated the progeny of a biparental cross while this study investigated several cultivars. The marker sp1 allowed Tamiru et al. [22] to observe two types of genotypes, one homozygous $\mathrm{AA}$ and one heterozygous $\mathrm{AB}$, which respectively corresponded to the male and the female phenotype. Contrary to this description, our results showed that the homozygous AA genotype was rather associated with the female sex and the heterozygous AB genotype with the male sex in the Beninese cultivars of $D$. rotundata. Thus, our results suggested that cultivated white Guinea yam from Benin showed rather a heterogametic male XX/XY system based on sp1 marker analysis. Our hypothesis is in accordance with the genetic control of other yam species. Indeed, according to Martin et al. [28], males are characterized by a heterogametic XY system in the genus Dioscorea. The male heterogametic XY system was confirmed in D. foribunda $[27,28]$ and in D. tokoro [37]. More recently, the heterogametic XY system was also confirmed in D. alata [27], a species that belongs to the Enantiophylum section of the Dioscorea genus, such as D. rotundata. [27]. 
Some authors suggested that the presence of a few homozygous males and heterozygous females is due to a transition from a heterogametic male $\mathrm{XX} / \mathrm{XY}$ system to a heterogametic female $\mathrm{ZZ/ZW}$ system [27], while others suggested that it is more the result of rare spontaneous hybridizations that the species has undergone in the past [38,39]. Both hypotheses are plausible in our case. On the one hand, the fact that the sp1 marker co-segregates with the male sex favors the second hypothesis. On the other hand, the presence of the genotypes $\mathrm{BB}$ and $\mathrm{AC}$, although very infrequent and of little-known origin to be informative, suggests that there is a beginning of reorganization of the heterogametic $X X / X Y$ system within $D$. rotundata from Benin, which thus favors the first hypothesis. In addition, the presence of the $\mathrm{W}$ allele (sp16) in $66 \%$ of analyzed individuals (including $42 \%$ of male individuals) and the fact that the sp16 marker did not allow good sex discrimination in our study for cultivars from Benin also favor the idea of a system in transition in white Guinea yam from Benin. Furthermore, we observed secondary amplifications for the sp 1 marker in $60 \%$ of the individuals, mainly in cultivars with unstable sex identity. Even if the source of such amplifications is still unknown, they could reflect the strong recombination of this locus and could suggest a process in transition. Tostain et al. [2] investigated the genetic diversity of white Guinea yam cultivars of Benin, including most cultivars analyzed in this study, using simple sequence repeat (SSR) markers. They observed that, in Benin, yam genetic diversity is organized according to cropping regions [2]. They also observed genetic differentiation according to the sex of the cultivars although this relationship requires further investigation. It would be interesting to compare the chromosome organization between lines with stable sexual identity and lines with unstable sexual identity in order to see if the clue of sexual identity is in the chromosome makeup. In the same vein, comparing the sequences of pseudo chromosome 11 in line with stable and unstable sex (F vs. F+ and M vs. M+) could identify key genes and alleles in sexual determination. Our observations and the existence of sexual variations over years and locations in some cultivars suggested that sexual determination is not exclusively under genetic control. It would thus also be necessary to investigate genotype-environment interactions in sex expression and explore whether sex determination of $D$. rotundata could be partly under epigenetic control.

\section{Conclusions}

After analysis of 119 individuals with sp16 and sp1 markers, our results showed that neither the sp16 nor the sp1 markers allowed a clear sex discrimination in the cultivated $D$. rotundata yams from Benin. We nevertheless observed that the best determinant of stable male cultivars was the absence of the sp16 marker and that the best determinant of stable female cultivars was the AA genotype of the sp1 marker. However, several cultivars had an unstable sex identity. Moreover, high ploidy level was associated with male or non-flowering phenotype, despite the presence of the female $\mathrm{W}$ allele. Analysis of the sp1 marker suggested that cultivated white Guinea yam from Benin showed a heterogametic male XX/XY system. However, the variability of our results pushes in favor of the possibility of a reorganization of this system and its transition to a ZZ/ZW system, but this hypothesis remains to be verified. Therefore, further and in-depth studies are required to elucidate the systems governing sexual chromosomes for a better understanding of sex determination in cultivated $D$. rotundata yams.

Supplementary Materials: The following are available online at http://www.mdpi.com/2073-4395/10/10/1521/s1, Table S1: List of the cultivars analyzed with indication of the sex, flowering history, ploidy level and results for sp16 and sp1 markers. Figure S1. Comparison of the sp16 marker sequence in female and male individuals of D. rotundata from Benin. The aligned sequences are consensus sequences of two female and three male individuals from different cultivars. Figure S2. Analysis of the genetic marker sp16 in a few cultivars of D. rotundata from Benin. Dr-Actine is used as a positive control. These gels are the same as shown in Figure 2. M, stable male; $\mathrm{M}+$, unstable male; F, stable female; F+, unstable female; O, monoecious; and N, non-flowering.

Author Contributions: Conceptualization, M.Q., N.D. and C.G.; methodology, N.D. and M.Q.; formal analysis, N.D.; investigation, N.D.; resources, M.Q, C.G., J.Z. and A.A.M. writing-original draft preparation, N.D. and M.Q.; writing-review and editing, N.D., M.Q, C.G, J.Z. and A.A.M.; supervision, M.Q. and C.G.; project administration, M.Q. and C.G. All authors have read and agreed to the published version of the manuscript.

Funding: This research received no external funding. N.D. is grateful to the International Action Committee (CAI) of UCLouvain for the funding of his PhD grant. 
Acknowledgments: The authors are grateful to the Centre de Recherche, de Formation, d'Incubation et d'Innovation pour le Développement Agricole (CREFIISDA, Benin) for access to their D. rotundata yam collection and for sampling of leaf material. We are also grateful to Paulin SEDAH (LGBMAG/UAC, Benin) for technical assistance.

Conflicts of Interest: The authors declare no conflict of interest. The funders had no role in the design of the study; in the collection, analyzes, or interpretation of data; in the writing of the manuscript, or in the decision to publish the results.

\section{References}

1. Coursey, D.G. The Civilizations of the Yam: Interrelationships of Man and Yams in Africa and the Indo-Pacific Region. Archaeol. Phys. Anthr. Ocean. 1972, 7, 215-233.

2. Tostain, S.; Agbangla, C.; Scarcelli, N.; Mariac, C.; Daïnou, O.; Berthaud, J.; Pham, J.-L. Genetic diversity analysis of yam cultivars (Dioscorea rotundata Poir.) in Benin using simple sequence repeat (SSR) markers. Plant Genet. Resour. 2007, 5, 71-81. [CrossRef]

3. Fakorede, J.; Faouziath, S.; Loko Yêyinou, L.E.; Dassou, G.A.T.; Tchekessi, C.; Ogundipe, O.; Bokossa, Y.I.; Dansi, A.A. Evaluation of proximate, sugars and mineral compositions of 48 yam (Dioscorea rotundata) cultivars used as parents in a breeding program in Republic of Benin. Int. J. Curr. Microbiol. Appl. Sci. 2020, 9, 1663-1682. [CrossRef]

4. Dansi, A.; Pillay, M.; Mignouna, H.D.; Daïnou, O.; Mondeil, F.; Moutaïrou, K. Ploidy level of the cultivated yams (Dioscorea cayenensis/D. rotundata complex) from Benin Republic as determined by chromosome counting and flow cytometry. Afr. Crop Sci. J. 2000, 8. [CrossRef]

5. Yolou, M.; Zoundjihekpon, J.; Assaba, E.I.; Anizehou, I.; Akoegninnou, A. La floraison des ignames africaines cultivées (D. cayenensis-D. rotundata et $D$. dumetorum) dans les champs des producteurs du Centre-Bénin. J. Appl. Biosci. 2015, 91, 8480-8492. [CrossRef]

6. Zoundjihekpon, J.; Essad, S.; Toure, B. Dénombrement chromosomique dans dix groupes variétaux du Complexe Dioscorea cayenensis-rotundata. Cytologia 1990, 55, 115-120. [CrossRef]

7. Lim, T.K. Dioscorea rotundata. In Edible Medicinal and Non-Medicinal Plants: Volume 10, Modified Stems, Roots, Bulbs; Lim, T.K., Ed.; Springer Netherlands: Dordrecht, The Netherlands, 2016; pp. 291-300. ISBN 978-94-017-7276-1.

8. Darkwa, K.; Olasanmi, B.; Asiedu, R.; Asfaw, A. Review of empirical and emerging breeding methods and tools for yam (Dioscorea spp.) improvement: Status and prospects. Plant Breed. 2020, 139, 474-497. [CrossRef]

9. Girma, G.; Natsume, S.; Carluccio, A.V.; Takagi, H.; Matsumura, H.; Uemura, A.; Muranaka, S.; Takagi, H.; Stavolone, L.; Gedil, M.; et al. Identification of candidate flowering and sex genes in white Guinea yam (D. rotundata Poir.) by SuperSAGE transcriptome profiling. PLoS ONE 2019, 14, e0216912. [CrossRef]

10. FAOSTAT. Available online: http://www.fao.org/faostat/en/\#home (accessed on 15 April 2019).

11. Loko, Y.L.; Dansi, A.; Agre, A.P.; Akpa, N.; Dossou-Aminon, I.; Assogba, P.; Dansi, M.; Akpagana, K.; Sanni, A. Perceptions paysannes et impacts des changements climatiques sur la production et la diversité variétale de l'igname dans la zone aride du nord-ouest du Bénin. Int. J. Biol. Chem. Sci. 2013, 7, 672-695. [CrossRef]

12. Degras, L. L' Igname, plante à tubercule tropicale. In Techniques Agricoles et Productions Tropicales; G.P. Maisonneuve \& Larose: Paris, France, 1986; ISBN 978-2-7068-0915-6.

13. Bousalem, M.; Dallot, S.; Guyader, S. The use of phylogenetic data to develop molecular tools for the detection and genotyping of Yam mosaic virus. Potential application in molecular epidemiology. J. Virol. Methods 2000, 90, 25-36. [CrossRef]

14. Egesi, C.N.; Onyeka, T.J.; Asiedu, R. Environmental stability of resistance to anthracnose and virus dyases of water yam (Dioscorea alata). Afr. J. Agric. Res. 2009, 4, 113-118.

15. Amusa, N.A.; Adigbite, A.A.; Muhammed, S.; Baiyewu, R.A. Yam diseases and its management in Nigeria. Afr. J. Biotechnol. 2003, 2, 497-502. [CrossRef]

16. Ogaraku, A.O.; Usman, H.O. Storage Rot of Some Yams (Dioscorea spp) in Keffi and Environs, Nasarawa State, Nigeria. Patnsuk J. 2008, 4, 22-27.

17. Asala, S.; Alegbejo, M.D.; Kashina, B.; Banwo, O.O.; Asiedu, R.; Kumar, P.L. Distribution and incidence of viruses infecting yam (Dioscorea spp.) in Nigeria. Glob. J. Biotechnol. Biosci. 2012, 1, 163-167.

18. Ayisah, K.D.; Gumedzoe, Y.M.D. Genetic diversity among yam mosaic virus (YMV) isolates infecting yam of the complex Dioscorea cayenensis rotundata in Togo. Int. J. Biol. Chem. Sci. 2012, 6, 1090-1101. [CrossRef] 
19. Thouvenel, J.C.; Dumont, R. Perte de rendement de l'igname infectée par le virus de la mosaique en Côte d'Ivoire. L'Agron. Trop. 1975, 45, 125-129.

20. Yolou, M.; Anizehou, I.; Dossou-Yovo, R.; Akoegninnou, A.; Zongo, J.D.; Zoundjihekpon, J. Etat des lieux de la reproduction sexuée des ignames africaines Dioscorea cayenensis-Dioscorea rotundata cultivées au Bénin. Int. J. Biol. Chem. Sci. 2015, 9, 737-750. [CrossRef]

21. Assaba, E.; Yolou, M.; Totin, V.; Quenum, H.; Zoundjihekpon, J. Caractéristiques des graines d'ignames cultivées du complexe d'espèces Dioscorea cayenensis-Dioscorea rotundata et évolution du taux de germination des graines. J. Afr. Sci. 2018, 14, 198-208.

22. Tamiru, M.; Natsume, S.; Takagi, H.; White, B.; Yaegashi, H.; Shimizu, M.; Yoshida, K.; Uemura, A.; Oikawa, K.; Abe, A.; et al. Genome sequencing of the staple food crop white Guinea yam enables the development of a molecular marker for sex determination. BMC Biol. 2017, 15, 86. [CrossRef]

23. Girma, G.; Hyma, K.E.; Asiedu, R.; Mitchell, S.E.; Gedil, M.; Spillane, C. Next-generation sequencing based genotyping, cytometry and phenotyping for understanding diversity and evolution of guinea yams. Theor. Appl. Genet. 2014, 127, 1783-1794. [CrossRef]

24. Daïnou, O.; Agbangla, C.; Berthaud, J.; Tostain, S. Le nombre chromosomique de base des espèces de Dioscorea constituant la section Enantiophyllum pourrait être égal a X=20. Quelques preuves. Ann. Sci. Agron. 2002, 3. [CrossRef]

25. Scarcelli, N.; Daïnou, O.; Agbangla, C.; Tostain, S.; Pham, J.-L. Segregation patterns of isozyme loci and microsatellite markers show the diploidy of African yam Dioscorea rotundata $(2 \mathrm{n}=40)$. Theor. Appl. Genet. 2005, 111, 226-232. [CrossRef] [PubMed]

26. Arnau, G.; Nemorin, A.; Maledon, E.; Abraham, K. Revision of ploidy status of Dioscorea alata L. (Dioscoreaceae) by cytogenetic and microsatellite segregation analysis. Theor. Appl. Genet. 2009, 118, 1239-1249. [CrossRef] [PubMed]

27. Cormier, F.; Lawac, F.; Maledon, E.; Gravillon, M.-C.; Nudol, E.; Mournet, P.; Vignes, H.; Chaïr, H.; Arnau, G. A reference high-density genetic map of greater yam (Dioscorea alata L.). Theor. Appl. Genet. 2019, 132, 1733-1744. [CrossRef]

28. Martin, F.W. Sex Ratio and Sex Determination in Dioscorea. J. Hered. 1966, 57, 95-99. [CrossRef]

29. Dansi, A.; Mignouna, H.D.; Zoundjihékpon, J.; Sangare, A.; Asiedu, R.; Quin, F.M. Morphological diversity, cultivar groups and possible descent in the cultivated yams (Dioscorea cayenensis/D. rotundata) complex in Benin Republic. Genet. Resour. Crop Evol. 1999, 46, 371-388. [CrossRef]

30. Yolou, M. Diversité génétique des ignames africaines cultivées (Complexe Dioscorea cayenensis D. rotundata et D. dumetorum) et perception des paysans du Centre-Bénin des questions des droits de propriété intellectuelle. Ph.D. Thesis, Abomey-Calavi University, Cotonou, Benin, 2016; p. 155.

31. Fulton, T.M.; Chunwongse, J.; Tanksley, S.D. Microprep protocol for extraction of DNA from tomato and other herbaceous plants. Plant Mol. Biol. Report. 1995, 13, 207-209. [CrossRef]

32. RDevelopment; C.TEAM 2009. R: A Language and Environment for Statistical Computing; R Foundation for Statistical Computing: Vienna, Austria, 2012; Available online: http://www.R-project.org (accessed on 30 June 2019).

33. Lebot, V.; Abraham, K.; Kaoh, J.; Rogers, C.; Molisalé, T. Development of anthracnose resistant hybrids of the Greater Yam (Dioscorea alata L.) and interspecific hybrids with D. nummularia Lam. Genet. Resour. Crop Evol. 2019, 66, 871-883. [CrossRef]

34. Hamadina, E.I.; Craufurd, P.Q.; Asiedu, R. Flowering intensity in white yam (Dioscorea rotundata). J. Agric. Sci. 2009, 147, 469-477. [CrossRef]

35. Nwankwo, I.I.M.; Bassey, E.E. A study of variability and heritability for yield and yield related traits in guinea white yam (Dioscorea rotundata Poir.) genotypes in Umudike, Southeastern Nigeria. Wudpecker J. Agric. Res. 2013, 2, 122-127.

36. Alam, S.; Shylla, E.; Bora, P.; Saud, B.K. Genetic Variation in Different Cultivars of Greater Yam (Dioscorea alata). J. Root Crops 2014, 40, 1-5.

37. Terauchi, R.; Kahl, G. Mapping of the Dioscorea tokoro genome: AFLP markers linked to sex. Genome 1999, 42, 752-762. [CrossRef]

38. Scarcelli, N.; Tostain, S.; Vigouroux, Y.; Agbangla, C.; Daïnou, O.; Pham, J.-L. Farmers' use of wild relative and sexual reproduction in a vegetatively propagated crop. The case of yam in Benin. Mol. Ecol. 2006, 15, 2421-2431. [CrossRef] [PubMed] 
39. Chaïr, H.; Cornet, D.; Deu, M.; Baco, M.N.; Agbangla, A.; Duval, M.F.; Noyer, J.L. Impact of farmer selection on yam genetic diversity. Conserv. Genet 2010, 11, 2255-2265. [CrossRef]

(C) 2020 by the authors. Licensee MDPI, Basel, Switzerland. This article is an open access article distributed under the terms and conditions of the Creative Commons Attribution (CC BY) license (http://creativecommons.org/licenses/by/4.0/). 